\title{
Development of Online Learning Models to Improve Digital Literacy Capabilities of Students: a Preliminary Analysis
}

\author{
Iman Nurjaman, Suyitno Muslim, Etin Solihatin
}

\begin{abstract}
The purpose of this study was to identify the use of the web in student learning and analyzing the needs regarding the development of online learning models. In general, this study uses a research and development approach by adopting the Analysis, Design, Development, Implementation and Evaluation (ADDIE model). At this stage of the analysis, it is done by identifying the use of the web in student learning and the opinions of students and lecturers regarding the development of online learning models, using online surveys on students and lecturers. The results of preliminary studies on the use of the web in learning showed that the percentage for reading using digital technology tended to be low at $22.5 \%$ of students stated that they rarely read and $59.2 \%$ stated that they sometimes read, $47.9 \%$ of students sometimes sought academic information and $57.1 \%$ sometimes - sometimes use the web to complete tasks related to student studies. As for opinions on the development of learning models from 76 students stated, $2(2.63 \%)$ stated that there is no need to develop online learning models, $69(90.79 \%)$ stated that the development of online learning models was needed and 5 (6.58\%) stated that it was necessary to develop online learning models. The same opinion was also conveyed by lecturers regarding the development of online learning models from 139 lecturers $(69.23 \%)$ stating that the development of online learning models was needed and 4 (30.77\%) stated that it was necessary to develop an online learning model. In general, the use of the web for learning in the low category and the high opinion regarding the need for online learning models for learning, so that further research is needed to develop an Online Learning Model to Improve Students' Digital Literacy Capabilities.
\end{abstract}

Keywords : online learning model, web, digital literacy, ADDIE.

\section{INTRODUCTION}

Digital technology has promoted a new vision for learning (1). Technology advancement has enabled internet penetration into every part of our lives, and we are spending more time on internet (2). Online learning is part of the modern transformation of higher education. Online learning modes continue to grow in popularity in higher education,

Revised Manuscript Received on November 15, 2019.

Mahesh Mudavath and K. Hari Kishore, Koneru Lakshmaiah Education Foundation, Vaddeswaram, Guntur District, Andhra Pradesh, India.

Vaagdevi College of Engineering, Bollikunta, Warangal (T.S), India. Email: mahichauhan@gmail.com

Srinivas Bhukya, Sri Indu College of Engg. \& Tech. Ibrahimpatnam, Ranga Reddy Dist. Email: srinivasb.ce@gmail.com

Babu Gundlapally and Prashanth Chittireddy, Vaagdevi College of Engineering, and VEC Bollikunta, Warangal (T.S), India. Email: babugundlapally@gmail.com, gani.vasu@gmail.com with the aim of streamlining and improving student learning,supporting collaboration and creativity, and equipping students with the skills they need to work and live in an increasingly digital world. Online learning saves time, reduces costs, offers a variety of media that match different learning styles, allows students to study anywhere at any time outside the classroom, overcomes the shortcomings of teaching staff, and has the potential to shift the learning process from teacher-centered learning to active student-centered learning. Allen \& Seaman (2011), most higher education institutions regard online learning as an important part of their education strategy (3) World Wide Web or abbreviated web is a growing international phenomenon with a strong presence in North America, Europe and Asia East. The web has a transformative effect on developed countries in Europe, Asia and North America, where it impacts on education, business and social life. The results of the study of 451 respondents who were students enrolled in various universities in Spain showed that the use of the web for learning was generally very poorly used for learning especially for reading, exchange of notes and completion of study assignments (4). As online learning develops, colleges and universities must find more ways to support the development of digital literacy because digital skills are important for online learning, economic productivity, and community involvement (5). Already a lot of research has been done regarding online learning. The research conducted by Asiry aims to identify students' readiness for online learning, to investigate their preferences and perceptions, and to measure the quality of online tutorials. The results of the study showed, overall, positive student attitudes towards online learning. Students view online learning as a useful complement to their learning rather than as a substitute for traditional teaching methods (3). Casey \& Hallissy examines technological innovation in the field of online teaching, which is computer-mediated communication (CMC) technology that has developed in recent years and is now quite popular in many higher education using online systems. The results showed that there is currently a lack of knowledge in relation to lecturers and tutors of higher education using CMC technology (Computer-mediated communication (CMC) (6). Gulateee, Pagram \& Combes examines the devices that students use in class, how students use online learning systems such as those provided by universities, and the 


\section{Development of Online Learning Models to Improve Digital Literacy Capabilities of Students: A Preliminary Analysis}

level of student skills when using technology for learning.

The results showed that students had intermediate skill levels when using basic software programs for their studies, while their social media skills advanced. students use mobile devices (cellphones and tablets) to access online learning materials. Overall, most students and staff do not have basic knowledge in using information technology for study purposes (7).Based on the explanation above, technological developments have encouraged changes in online learning patterns but online learning itself requires digital literacy capabilities so that students can follow the changes in learning patterns. While the results of previous studies indicate that the digital literacy ability of students is still low. Of the many studies related to online learning there has been no research and development (Research \& Development) regarding the development of online learning learning models to improve student digital literacy skills. This article uses the ADDIE approach, the first step of the five steps is identification and analysis of needs Based on this description, the researcher identifies and needs analysis of model development online learning to improve students 'digital literacy skills, as a basis for the next stage, namely the development of online learning models to improve students' digital literacy skills

\section{LITERATURE REVIEW}

\section{A. Model Learning}

Models help us make the concept of representation reality. Models are simple representations of more complex forms, processes, and functions of phenomena or ideas (8). Models are simple representations of physical forms, processes, and functions of more complex phenomena. Richey revealed the same thing, that the model is a representation of reality that is presented in a complete structure and sequence. Models usually provide an ideal and simple view of reality (9). The model is a projection because it implies something projected (original)(10). Furthermore, Harre in Richey identified two types of models, namely micromorph and paramorph (9). Micromorphs are physical forms, visual replicas, such as computer simulations or small-scale objects from actual large objects. While paramorph is a symbolic model that uses verbal descriptions. Paramorph can be divided into three categories, namely: (1) conceptual models, (2) procedural models, and (3) mathematical models. Suparman (2012) states, 'The model is a representation of reality that describes the structure and order of a concept and displays one form of four forms as follows: verbal or conceptual descriptions, steps of activities or procedures, physical or visual replicas, equations or formulas"(11). Learning by Schunk is "an enduring change in behavior, or in the capacity to behave in a given fashion, which results from practice or other forms of experience (12). According to Gredler learning is a process in which humans gain a range and variety of skills, knowledge, and attitudes that distinguish them from other species (13). Learning is capable of doing something after that that you cannot do before (JC Cronje, 2018). Vygotsky
(1978) in Harmon (2018) found that learning occurs in a social context through dynamic interactions with teachers, peers, and content. (14). Smith and Ragan define learning as "the intentional facilitation of learning toward identified learning goals (15) or learning is intentional learning facilitation carried out to achieve learning goals. Learning is a change in behavior (behavior) as learning outcomes in the form of knowledge, skills, attitudes, and / or behavior (16). Learning is done to help students learn (17).

Based on the explanation above, the learning model is related to explanation previously, it was a representation of reality with a clear and complete sequence and structure and presented one form. The learning model in this study was a series of integrated components to facilitate learning. There are two types of models developed in this study, namely conceptual models and physical models The conceptual model provides an illustration about online learning to be developed

\section{B.Online Learning}

Learning allows flexibility of access, from anywhere and usually at any time - basically, it allows participants to break down time and space (Cole, 2000) - however, learning materials must be well designed to involve students and promote learning. According to Rossett (2002), online learning has many promises, but it requires commitment and resources, and it must be done right. "Doing it right" means that online learning material must be properly designed, with learners and learning being focused, and that adequate support must be provided. Ring and Mathieux (2002) suggest that online learning must have high authenticity (that is, students must learn in the context of the workplace), high interactivity, and high collaboration. Various terminologies have been used for online learning, a fact that makes it difficult to develop generic definitions. Commonly used terms include e-learning, Internet learning, distributed learning, networked learning, tele-learning, virtual learning, computer-assisted learning, web-based learning, and distance learning. All of these terms imply that students are far from tutors or instructors, that students use some form of technology (usually computers) to access learning materials, that students use technology to interact with tutors or instructors and other students, and that some form of support is given to students ... There are many definitions of online learning in the literature, definitions that reflect the diversity of related practices and technologies. Carliner (1999) defines online learning as educational material presented on computers. Khan (1997) defines online instruction as an innovative approach to convey instruction to a remote audience, using the Web as a medium. However, online learning involves more than just presentation and delivery of material using the Web: students and the learning process must be the focus of online learning. Based on this description, define online learning as the use of the Internet to access learning materials; to interact with content, instructors, and other students; and to get support during the learning process, to gain 
knowledge, to build personal meaning, and to grow from learning experience (18). Online learning is the process of conveying instructions and content especially through the Internet.

Used interchangeably with virtual learning, Cyber learning, e-learning. Students can participate in online learning through one course (additional), or school or a program completely online.(19). In the 2006 International Perspective publication on K-12 Online Learning iNACOL described online learning as: including a range of web-based resources, media, tools, intera ctivity, and curricular or teaching approaches. Internationally, various terms are used to describe online learning including distance education, virtual schools, virtual learning, e-learning, electronic learning. In general, the general theme is the type of learning that occurs through the Internet. (19).

\section{Digital Literacy}

Literacy was introduced in 1997 by Paul Gilster in his book Digital Literacy where the authors offer definitions that focus on the ability to understand, appreciate, and use information in various formats that can be conveyed by computers. Gilster (1997) asserts that one should not consider digital literacy only as a way of using the internet. The ability to evaluate and interpret information is very important, through digital literacy one acquires basic thinking skills and core competencies without which he cannot direct and perform tasks in an interactive environment (20)-(21). The term 'digital literacy' was originally used to refer to a set of minimal technical skills that allowed technology users to operate effectively and to perform basic tasks (Buckingham, 2010). This functional definition defines the basic skills needed to carry out certain operations. However, it failed to recognize that digital literacy now means more than the technical skills involved in using computers. This also means knowing how to do an online search (for example, in a database using a Boolean operator, not just to search on Google) or send an email. Computers and other mobile devices provide opportunities to express themselves, play, and communicate and act as a medium where personal relationships can be experienced. Smart phones, for example, are now marketed as lifestyle companions, not communication devices. Thus, a person's ability to learn effectively in the digital world needs to consider a broader range of skills and literacy than just technical abilities (22). Bawden (2018) states the term digital literacy has been expanded and now covers all the specific skills and competencies needed to find, find, evaluate, and handle information in a computerized form (20).In order to use technology effectively for learning, one needs to have a certain level of digital literacy. Digital literacy for learning is more than just knowing how to operate technology, but also having the right information management and critical thinking skills, as well as appropriate online behavior (23).

\section{METHODOLOGY}

\section{A. Method}

Research uses a research and development approach with the aim of producing an online learning model through development and validation referring to the ADDIE model (Analysis, Design, Development, Implementation, and Evaluation) (24).Data collection is done by distributing questionnaires online. In the questionnaire two things identified were the use of the web in learning and the need for online learning models. The first stage in ADDIE is needs analysis, literature study and small research.

\section{B. Need Analysis}

This is done by looking for information related to the problems faced by the location or area that is the target of product development. Also, look for information or data related to what is needed to solve the problem.

\section{Literature Study}

Deals with the search for information and empirical data through theories and research related to products to be developed. This will lead researchers to develop products to be produced.

\section{Small-scale research}

Intended as a result of identification carried out by researchers related to the products needed to ascertain whether the products to be developed by researchers can truly be products that can solve institutional problems education. stage of the ADDIE stage, activities are carried out: data collection and needs analysis. Needs analysis is done on students.

\section{RESULTS AND DISCUSSION}

This study was conducted on 76 students. the results of the study show that the use of the web for learning is in a low category, and students generally need the development of online learning models. The following are the results of identifying web usage and student needs for the development of online learning models. The results show that the percentage for reading using digital technology tends to be low at $22.5 \%$ of students stated that they rarely read and $59.2 \%$ stated that they sometimes read, $47.9 \%$ of students sometimes sought academic information and $57.1 \%$ sometimes used the web to complete tasks related to student studies.Students are used to using technology, but not all students understand the use of technology for learning. This is where the importance of students has digital literacy skills. Digital literacy is a prerequisite for expanding access to technology and information. Although students use technology in their daily activities, they may not be familiar with or use technology for learning (6). Students may use more technology for social or entertainment purposes but not for learning (23). Gurung and Rutledge (2014) share the view that digital learners need help on how to use technology effectively for learning. $\mathrm{Ng}$

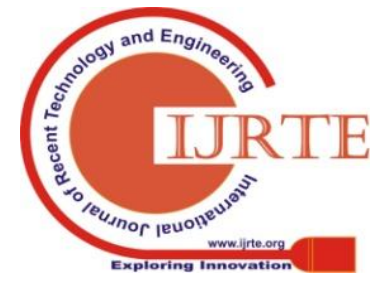




\section{Development of Online Learning Models to Improve Digital Literacy Capabilities of Students: A Preliminary}

Analysis

(2012) argues that students may not know how to use technology to study. However, they already have a certain level of digital literacy, they must be able to learn to use technology to learn easily. Other research shows that students use mobile devices (cellphones and tablets) to access online learning materials. In general, most students do not have basic knowledge in using information technology for study purposes (23). Other research shows that students use mobile devices (cellphones and tablets) to access online learning materials. In general, most students do not have basic knowledge in using information technology for study purposes (7).

The study finds the web is a favorite media in student life but it is not the main thing and does not make students use the web in their learning process on campus.

Student Opinions Regarding The Development Of Online Learning Models

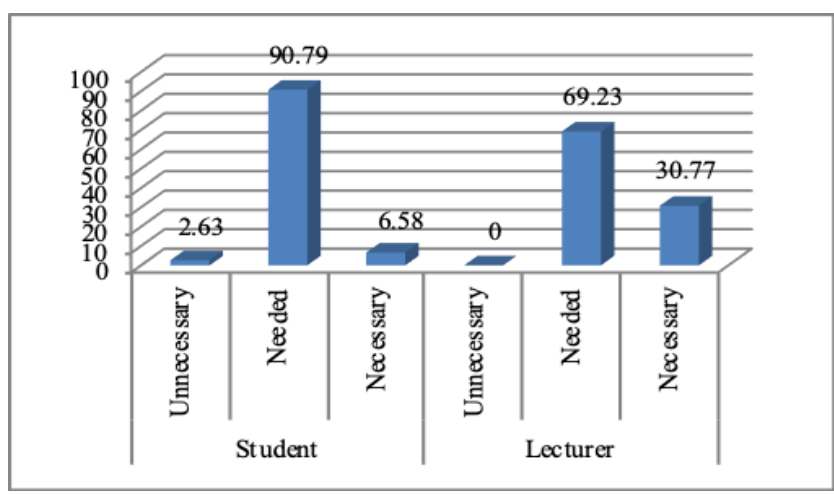

Fig. 1. Student and Lecturer opinions regarding the development of online learning models

Based on the explanation above the web is one of the media that can be used to deliver online content and can be combined with the use of social networks such as Twitter, WA, Line, Facebook. To find out the needs and opinions of students regarding the online learning model, the results of the initial study showed that 76 students stated, 2 (2.63\%) stated that there was no need to develop an online learning model, $69(90.79 \%)$ stated that the development of online learning models was needed and $5(6.58 \%)$ states that it is necessary to develop an online learning model. The same opinion was also conveyed by lecturers regarding the development of online learning models from 13, 9 lecturers $(69.23 \%)$ stating that the development of online learning models was needed and $4(30.77 \%)$ stated that it was necessary to develop an online learning model. When online learning develops, colleges and universities must find more ways to support the development of digital literacy because digital skills are important for online learning, economic productivity, and community involvement (Bach, Shaffer, \& Wolfson, 2013). If innovative initiatives to close the digital divide on campuses are not implemented and assessed, higher education institutions run the risk of perpetuating social inequality by failing to give all students the skills needed for full participation in economic, social and citizenship (5). The development of learning models becomes very important and must be done immediately because highly technological developments change the patterns of interaction and learning patterns. Online learning models that are in line with technological developments greatly provide many advantages, conveniences and benefits, one of which is student digital literacy skills

\section{CONCLUSION}

The online learning model must be developed because technological developments are rapidly changing learning patterns. One form of online learning is web-based. The use of the web in learning is something that must be mastered by students, but it turns out that the high use of technology by students is not used for learning and in general this is due to the low digital literacy abilities of students. Therefore, it is necessary to develop an online learning model to improve students' digital literacy skills.

\section{REFERENCES}

1. Gros B. The design of smart educational environments. Smart Learn Environ [Internet]. 2016;3(1):15. Available from: http://slejournal.springeropen.com/articles/10.1186/s40561-016-0039-x

2. Bruntha P, Yasmeen A, Indirapriyadharshini B, Giri N. Millennials Attitude on Effectiveness of Online Advertisement. Int J Eng Adv Technol. 2019;(2):120-3.

3. Asiry MA. Dental students' perceptions of an online learning. Saudi Dent J [Internet]. 2017;29(4):167-70. Available from: https://doi.org/10.1016/j.sdentj.2017.03.005

4. Figaredo DD. Heuristics and web skills acquisition in open learning environments. Educ Technol Soc. 2017;20(4):102-11.

5. Smith S. Supporting Digital Literacy across the Curriculum through Blended Support: A Pilot Project Report. J Educ Technol Syst. 2014;43(2):189-98.

6. Casey L, Hallissy M. Live Learning: Online Teaching, Digital Literacy and the Practice of Inquiry. Irish J Technol Enhanc Learn. 2014;1(1):1-7.

7. Gulateee Y, Pagram J, Combes B. Which Tech Will I Use? Trends in Students' Use and Ownership of Technology in a Thai University, an Ongoing Study. J ICT Res Appl. 2018;12(2):138.

8. Gustafson, Kent L., \& Branch MR. Survey of Instructional Development Models. 1997. p. 108.

9. C. Richey R, D. Klein J, W. Tracey M. The Instructional Design Knowledge Base: Theory, Research, and Practice. New York : Routledge; 2011.

10. Mcnamara JF. What is a Model? Int J Educ Reform. 2019;5(4):517-20.

11. Suparman MA. Desain Instruksional Modern : Panduan Para Pengajar dan Inovator Pendidikan. I. Sallama N, editor. Erlangga; 2014. 379 p.

12. H. Schunk D. Learning Theories : An Educational Perspective. Sixth Edit. Pearson; 2012.

13. Gredler ME. Learning and instruction: Theory into practice [Internet] Theory and Practice. 2009. xi, 340 p. Available from: www.pearsonhighered.com

14. Persichitte KA. Educational Technology to Improve Quality and Access on a Global Scale. In 2018. Available from: http://link.springer.com/10.1007/978-3-319-66227-5

15. Smith PL, Tillman J R. Instructional Design. Third Edit. New York: John Wiley \& Sons, Inc.; 2005. 402 p.

16. Suparman MA. Teknologi Pendidikan Dalam Pendidikan Jarak Jauh Solusi untuk Kuallitas dan Aksesibilitas Pendidikan. Kesatu. Setijadi, editor. Universitas Terbuka; 2014.

17. M. Gagne R, W. Wager W, C. Golas K, M. Keller J. Principles of Instructional Design. Fifth. California: Thomson Wadsworth; 2005.

18. van Bruggen J. Theory and practice of online learning [Internet]. British Journal of Educational Technology. 2005. 5 p. Available from: http://doi.wiley.com/10.1111/j.1467-8535.2005.00445_1.x

19. McLeod S, Richardson JW. Handbook of Research on K-12 online and blended learning [Internet]. Ferdig RE, Kennedy K, editors. Handbook of Research on K-12 Online and Blended Learning. ETC Press; 2014. 285-302 
http://press.etc.cmu.edu/files/Handbook-Blended-Learning_Ferdig-Kenne dy-etal_web.pdf

20. Shopova T. Digital Literacy of Students and Its Improvement At the University. ERIES J [Internet]. 2016;7(2):2-3. Available from: doi: 10.7160/eriesj.2014.070201

21. Lankshear C, Knobel M. Digital Literacy and Digital Literacies: - Policy, Pedagogy and Research Considerations for Education. Nord J Digit Lit [Internet]. 2015;10(Jubileumsnummer):8-20 ER. Available from: http://www.idunn.no/dk/2015/Jubileumsnummer/digital_literacy_and_di gitalliteracies_-_policy_pedagogy

22. Burton LJ, Summers J, Lawrence J, Noble K, Gibbings P. Digital Literacy in Higher Education: The Rhetoric and the Reality BT - Myths in Education, Learning and Teaching: Policies, Practices and Principles. In: Harmes MK, Huijser H, Danaher PA, editors. London: Palgrave Macmillan UK; 2015. p. 151-72. Available from: https://doi.org/10.1057/9781137476982_9

23. Tang CM, Chaw LY. Digital Literacy: A Prerequisite for Effective Learning in a Blended Learning Environment? 14th Eur Conf e-Learning, ECEL 2015 [Internet]. 2015;14(1):601-10. Available from: https://www.scopus.com/inward/record.uri?eid=2-s2.0-84977151316\&pa rtnerID=40\&md5=8b12c83ab9607a55596b8c0a050fa6bf

24. Branch RM, Dousay TA. Survey of Instructional Design Models. Fifth Edit. R. Walling. D, editor. Indiana USA: Association for Educational Communication and Technology; 2015. 1-106 p.

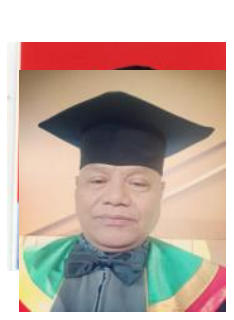

\section{AUTHORS PROFILE}

The author is a doctoral student majoring in Educational Technology at the Postgraduate of Universitas Negeri Jakarta. The author's research and writing has a lot to do with the use of technology and learning, model development and online learning. The direction of the researcher (roadmap) is the integration of technology in learning, namely developing and making linkages between technology, approaches and strategies in learning. The author's focus is to develop effective learning by using technology.

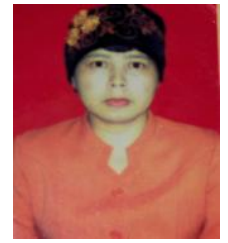

The author's activities besides lecturing are teaching in the Early Childhood Education Teacher Education study program at Universitas Muhammadiyah Tangerang and at the Open University in the Primary School Teacher Education study program. The author can be contacted via email: nurjamaniman@gmail.com

The author is a professor of educational technology who has written extensively on education and researches related to educational technology. The researcher is a lecturer in electrical engineering and postgraduate UNJ. Other than teaching and researching activities, he is also the head of a learning resource center at UNJ. The author can be contacted via email at Email: suyitno@unj.ac.id

the writer is a lecturer at the postgraduate of UNJ. Author of an educational technology doctor. Besides teaching, the writer is very active in conducting research and writing. Starting from 2014 until now the author about producing 35 writings. Writing in the form of a widely quoted book about cooperative learning analysis of social studies learning. to get in touch with the author via email at etin_solihatin@unj.ac.id 